\title{
PHLEBOTOMINAE FAUNA IN THE PROVINCE OF TUCUMÁN, ARGENTINA
}

\author{
Elizabeth CÓRDOBA LANÚS (1) \& Oscar Daniel SALOMÓN $(2,3)$
}

\begin{abstract}
SUMMARY
American Tegumentary Leishmaniasis is endemic in the province of Tucumán since 1916 where the first Argentinian case of leishmaniasis was reported. An epidemic outbreak took place in the province during 1986-1988, after that the number of cases increased gradually again between 1991-1996. Since October of 1999 sand flies captures were performed at different places associated with current and past transmission or sites identified as risky ones. The collections were carried out with CDC mini light trap and modified Shannon trap. In this study 2338 Phlebotominae were captured being prevalent Lutzomyia neivai (Lu intermedia complex) (97.7\%), followed by Lu. migonei. We report Lu. shannoni for the first time in the province. Phlebotominae was abundant in the warm and humid months and showed a peak before the summer rains. Lutzomyia neivai showed a pattern (peridomestic prevalence, anthropophilia, abundance in secondary forest) consistent with other outbreak studies. Thus, the results reinforce this species incrimination as vector of leishmaniasis in the area. Domestic animals close to houses increase its abundance, and so the probable associated risk of human-Phlebotominae contact. Further studies should be done to understand the role of each Phlebotominae species in the transmission of leishmaniasis in Tucumán in order to design entomological surveillance strategies.
\end{abstract}

KEYWORDS: Phlebotominae, Lutzomyia neivai, Tucumán, Argentina.

\section{INTRODUCTION}

Leishmaniasis is a re-emerging zoonosis of high impact on public health ${ }^{11,39}$. It is produced by parasites of the genus Leishmania ${ }^{2}$, and it is transmitted by small dipterous of the subfamily Phlebotominae ${ }^{20,21}$. In America tegumentary leishmaniasis (cutaneous and mucocutaneous) is endemic from the Yucatán peninsula to northern Argentina ${ }^{10,35,37,39}$. In Argentina this disease is endemic, and the parasite was identified as Leishmania (Viannia) braziliensi s $^{2,8,12,34,35}$. The first record in the country was in 1916, by PATERSON, in the province of Tucumán ${ }^{3,36}$, since then its vectorial transmission has been reported, in nine northwestern provinces: Jujuy, Salta, Tucumán, Santiago del Estero, Catamarca, Chaco, Formosa, Corrientes and Misiones ${ }^{4,37}$. In the 1980 decade an epidemic outbreak took place in Salta, the first recorded in the country, in rural and periurban areas, with similar incidence among sexes and cases among children. Since then human cases all over the Argentinian endemic area have registered an increase ${ }^{31}$. In the province of Tucumán an epidemic outbreak occurred in 1986-1988, with 118 reported cases, $95.31 \%$ of them autochthonous (incidence rate 12.1 per 100,000 inhabitants). Between 1991 and 1996, 232 new cases were reported in the province ${ }^{37}$. However, there are not data about Phlebotominae sand flies distribution in Tucumán after the entomological literature of the 1950 decade $^{9}$.

This study was performed in the province of Tucumán in order to describe the Phlebotominae fauna of the area and its distribution after the last epidemic outbreaks, mainly Lutzomyia neivai, suspected as the peridomestic major vector of tegumentary leishmaniasis in Argentina ${ }^{24}$.

\section{MATERIALS AND METHODS}

The area of study includes the following localities: El Cadillal $\left(26^{\circ}\right.$ 36' LS, 65 ${ }^{\circ} 12^{\prime}$ LO) Tafí Viejo department; El Timbó (26 41' LS, $65^{\circ}$ $08^{\prime}$ LO) and El Sunchal (26 36' LS, 65 $04^{\circ}$ LO), Burruyacú department, in the NE; Tte. Berdina, El Guayal (26 56' 35" LS, 65 26' 87' LO) Famaillá department, in the West-Center; El Molino (27 $19^{\prime}$ ' 87' LS, 65 39' 19' LO), Iltico (27 19' 87' LS, 65 39' 19” LO) Chicligasta department, and Yánima (27 $39^{\circ}$ LS, 65 $29^{\circ}$ LO $)$ La Cocha department, in the south of the province (Fig. 1). The sites of study belong to the phytogeographic province of the Yungas or the Tucumano- boliviana Jungle of the Amazonic Domain ${ }^{6,7}$.

Since October of 1999 sand flies were collected in sites associated with current and past transmission of leishmaniasis, or in the absence of recent cases in sites with phytogeographic characteristics potentially favorable for the development of Phlebotominae sand flies ${ }^{25}$.

A modified Shannon trap with protected human bait (SALOMÓN et al., 1995) and 2 CDC-like mini light traps, were used since the dusk for three hours. The Shannon trap was placed in areas of close vegetation, and the CDC traps, one no less than $50 \mathrm{~m}$ from the Shannon trap, and

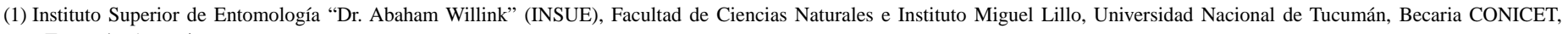
Tucumán, Argentina.

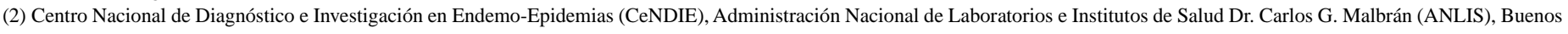
Aires, Argentina. 




Fig. 1 - Area of the study including the different localities.

the other in the border between primary and secondary vegetation. In the case of using more mini light traps, these were located in possible Phlebotominae rest sites (tree trunks, scratches, caves, etc) or in peridomestic habitats (animal pens, poultry yards, etc) of houses with human cases $^{15}$.
In December of 1999 at Yánima Shannon trap captures were performed in reference to a recent case, in peridomestic, secondary and primary forest ( $500 \mathrm{~m}$ from the dwelling) sites. The light trap were located in a pig pen $(50 \mathrm{~m})$, in the bushes close to a water stream $(20 \mathrm{~m})$, and in the primary forest. In the summer of 2000 the captures were repeated but the pig pen had been destroyed, so the CDC trap was then located in a tree where the poultry use to sleep.

The collected material was transferred dry to the laboratory where the insects were clarified and mounted (phenol - potassium hydroxide dehydration in etilic alcohol $\left(50^{\circ}-100^{\circ}\right)$ - diaphanization in vegetal creosota and mounting in balsam), and the species were determined ${ }^{38}$.

The continuity of 1999 and 2000 longitudinal captures at El Guayal were only interrupted by weather conditions or inavoidable operative difficulties.

\section{RESULTS}

A total of 2338 Phlebotominae were collected during the period of study. Sand flies were present in all the localities where the captures were performed, except in El Sunchal (trapping in the two consecutive summers).

The collected material corresponds to three species: Lutzomyia neivai (Lu. intermedia complex), Lu. migonei and Lu. shannoni, the last one cited for the first time in Tucumán ${ }^{4,10,22,24}$. Lutzomyia neivai was the most frequent species $(97.7 \%)$, followed by Lu. migonei $(2.3 \%)$, and 3 individuals of $L u$. shannoni (Table 1). The former species was prevalent in mini light CDC-like trap (sex ratio females: males 1.4:1), as in Shannon trap (sex ratio 4.1:1), it was present in every capture with at least an individual. Lutzomyia migonei was captured only with CDC trap in 8 opportunities (sex ratio 1.6:1), always together with Lu. neivai (Table 2). Lutzomyia shannoni was collected once, three females, in El Timbó (Table 1).

The captures by CDC-like trap and simultaneous Shannon trap do not show significant differences.

In the locality of Yánima 366 Phlebotominae were collected in December of 1999 and 30 in February of 2001. The relative abundance

Table 1

Captures by species, site of capture and date. Tucumán province, Argentina, 1999-2000

\begin{tabular}{|c|c|c|c|c|c|}
\hline Locality & Lu. neivai & Lu. migonei & Lu. shannoni & Date & Nights of capture \\
\hline El Guayal & 62 & 1 & 0 & $10 / 99$ to $11 / 00$ & 13 \\
\hline El Sunchal & 0 & 0 & 0 & $10 / 99 \& 2 / 01$ & 2 \\
\hline El Molino & 312 & 0 & 0 & $12 / 99$ & 1 \\
\hline Yánima & 395 & 1 & 0 & $12 / 99 \& 2 / 01$ & 2 \\
\hline Iltico & 1058 & 1 & 0 & $1 / 00 \& 12 / 00$ & 3 \\
\hline El Cadillal & 8 & 6 & 0 & $4 / 00$ & 1 \\
\hline Loma del Pila & 3 & 0 & 0 & $1 / 01$ & 1 \\
\hline Timbó & 0 & 0 & 3 & $5 / 01 \& 6 / 01$ & 4 \\
\hline Total & 1838 & 9 & 3 & & \\
\hline
\end{tabular}


Table 2

Captures of $\mathrm{Lu}$. migonei with CDC like trap by place and date, and $\mathrm{Lu}$. neivai collected in the same event. Tucumán province, Argentina, 1999-2000

\begin{tabular}{lccc}
\hline Locality & Date & Lu. migonei $(\mathrm{f} / \mathrm{m})$ & Lu. neivai $(\mathrm{f} / \mathrm{m})$ \\
\hline Yánima & $12 / 99$ & $1 / 0$ & $105 / 90$ \\
Iltico & $01 / 00$ & $1 / 0$ & $135 / 192$ \\
El Cadillal & $04 / 00$ & $3 / 3$ & $6 / 0$ \\
El Guayal & $12 / 00$ & $1 / 0$ & $7 / 1$ \\
El Guayal & $01 / 01^{*}$ & $23 / 17$ & $206 / 207$ \\
El Guayal & $02 / 01^{* *}$ & $6 / 1$ & $4 / 1$ \\
\hline
\end{tabular}

* 4 Traps, ** 2 traps

by site of capture with CDC trap was $1: 1.78: 4.36$ in primary forest: peridomestic secondary vegetation: pig pen, in the first year. The capture obtained in the primary forest with CDC was similar to the one obtained with Shannon trap (45 and 35 individuals respectively), and 3.5 times superior to the one obtained with CDC in the border of the primary forest close to the agriculture area. In the year 2001 the capture in primary forest was 0.28 times the capture of the year 1999 , and the relation primary forest: peridomestic tree with chickens was 1:2.3. The unique individual of $\mathrm{Lu}$. migonei was collected in the pig pen.

According to the results and the accessibility we have started a schedule of captures with CDC trap, every fifteen days, in El Guayal. In relation to the rainfall a peak of abundance of sand flies was observed in January of 2001 just before the summer rain, and after this period it was observed a decrease in the population density ( Fig. 2 ).

\section{DISCUSSION}

Phlebotominae were reported in Tucumán province after 40 years without entomological data. Three species were collected: Lutzomyia neivai (Pinto, 1926), Lu. migonei (França, 1920) and Lu. shannoni (Dyar, 1929). Lutzomyia neivai was previously identified as Lu. intermedia sensu lato (s.l.), but the two species of the Lu. intermedia complex were recently differentiated ${ }^{16,17,18}$. Lutzomyia intermedia sensu lato (s.l.) was



Fig. 2 - Phlebotominae abundance and weekly precipitation in El Guayal in the period December 2000 - June 2001. cited in Tafí Viejo, Río Chico and Yerba Buena departments, Tucumán up to $1950^{3,21}$. This species was again captured in this study in all the localities sampled, except in El Timbó, but the collections were performed in last autumn, so we can not discard its presence in other seasons. However, the relative abundance of $L u$. neivai (Lu. intermedia s.l.)/Lu. migonei was reversed since those first reports, and currently $L u$. neivai turned to be the prevalent species. This fact may be related to extensive deforestation, as it has been proposed for Brazil and Salta province, Argentina ${ }^{14,15,26,27}$.

The abundance of Lu. neivai in CDC and Shannon traps, in secondary forest and modified environments, its peridomestic prevalence related to human cases (in some occasions $100 \%$ ), as its anthropophilic habit (females ratio in Shannon trap with protected human bait) supports the hypothesis of its incrimination as the vector of leishmaniasis in the area. This is consistent with other outbreak studies in Argentina, in the same phytogeographic domain ${ }^{27,29,30,31}$. Although up to now there are not identified isolates, the clinical and epidemiological pattern of human cases in Tucumán are consistent with leishmaniasis due to Leishmania (Viannia) braziliensis ${ }^{35}$, the main parasite in the endemic region of Argentina. This fact is important if we consider that the species of the $L u$. intermedia complex had been found naturally infected with $L$. (Viannia) braziliensis in Brazi1 ${ }^{22,23}$. Thus, the sand fly attractiveness to animal (pigs, chicken) pens that increase its abundance would increase also the risk of Leishmania transmission, when the animal and human dwellings are close enough ${ }^{26,31}$. In Brazil, Lu. intermedia s.l. was found in chicken houses thorough the year, where it is sheltered during the winter $^{1,5}$.

Lutzomyia migonei was previously reported feeding on domestic animals in Chicligasta, Trancas, Tafí Viejo, Lules, Yerba Buena, Río Chico, Burruyacú departments, Tucumán ${ }^{3,21}$. In the current study it was collected in almost all the sampled sites, only by light trap and always together with $L u$. neivai, during the peaks of abundance of the latter. The relative abundance seems different in El Cadillal because Lu. neivai abundance remained low, but this species still showed the higher anthropophilia.

Longitudinal captures (El Guayal) resulted in a neat peak after a month of unusual low rainfall (December 2000: $56 \mathrm{~mm}$; December mean: $161 \mathrm{~mm})^{19}$, just before the summer rainfall season (January-March), when the sand fly abundance dropped dramatically. Phlebotominae populations showed the higher density peaks during the warm-humid months, and the lower in the cold-dry season, both in Brazil and Argentina foci ${ }^{1,13,14,30}$. But in Argentina the concentrated rainy season usually interrupts the spring-summer abundance peak ${ }^{28,33}$.

In conclusion, after 40 years three species were found in Tucumán province, Lu. neivai, Lu. migonei and Lu. shannoni, the last reported for the first time in the province, although it was cited in the adjacent provinces. Lutzomyia neivai in the current study became the prevalent species around peridomestic habitats related to human leishmaniasis cases, while the leishmaniasis incidence increased in the last twenty years. The Phlebotominae were present thorough the Tucuman - Bolivian phytogeographic environment, where the outbreaks of leishmaniasis may happen. Taking into account the precedent results, further studies will be done on the spatial and seasonal distribution of sand flies in order to contribute to design surveillance strategies based on entomological data ${ }^{26}$. 


\section{RESUMEN}

\section{Fauna flebotomínica en la Provincia de Tucumán, Argentina}

La Leishmaniasis Tegumentaria Americana es endémica en la provincia de Tucumán desde 1916, lugar donde se reportara el primer caso argentino de leishmaniasis. Entre 1986-88 ocurrió un brote epidémico en la provincia, después de este hecho el número de casos aumentó en forma gradual nuevamente entre los años 1991-1996. A partir de Octubre de 1999 se realizaron capturas de Phlebotominae en la provincia en diferentes sitios asociados con transmisión actual o pasada de leishmaniasis o en aquellos sitios identificados como de riesgo. Los muestreos se llevaron a cabo con mini trampa de luz tipo CDC y trampa Shannon modificada. En el presente estudio 2338 individuos fueron capturados e identificados siendo prevalente Lutzomyia neivai (Complejo Lu intermedia) (97.7\%), seguida de Lu. migonei. Se reporta por primera vez la presencia de Lu. shannoni para la provincia de Tucumán. Los datos preliminares muestran que estos insectos son abundantes en los meses cálidos y húmedos y presentan un pico de actividad anterior a las lluvias de verano. Lutzomyia neivai mostró un patrón (prevalencia peridomiciliaria, antropofilia, abundancia en bosque secundario) consistente con otros estudios de brotes epidémicos. De este modo, los resultados refuerzan la incriminación de esta especie como vector de leishmaniasis en el área. Los animales domésticos cercanos a las viviendas aumentan su abundancia, y por lo tanto el probable y asociado riesgo de contacto hombre - Phlebotominae. Estudios posteriores deben realizarse para comprender el rol de cada especie de Phebotominae en la transmisión de Leishmaniasis en Tucumán y así poder diseñar estrategias de vigilancia entomológica.

\section{ACKNOWLEDGMENTS}

To Dra. Mercedes Lizarralde de Grosso Director of INSUE for her valuable comments and support. To Lic. Lucrecia Augier, Lic. Gustavo Molina (INSUE) for their collaboration in the field. To Dr. Reynaldo Marcolongo (Municipality of Concepción), Dra. Ana María Andina (Hospital of Concepción). To the Staff of the Municipality of Concepción, and the SIPROSA south area. This work was possible with the support of CONICET, CIUNT and FONCYT.

\section{REFERENCES}

1. AGUIAR, G.M. de \& SOUCASAUX, T. - Aspectos da ecologia dos flebótomos do Parque Nacional da Serra dos Órgãos, Rio de Janeiro. I. Freqüência mensal em isca humana (Diptera, Psychodidae, Phlebotominae). Mem. Inst. Oswaldo Cruz, 79: 197-209, 1984.

2. BIAGINI, R.; RIVERO, M.; FLEMING, A.; FARJAT, R. \& ARREBANEL, A.M. Leishmaniasis americana. Sem. méd. (B. Aires), 151: 363-369, 1977.

3. BEJARANO, J.F.R. \& DURET, J.P. - Contribución al conocimiento de los flebótomos argentinos (Diptera: Psychodidae). Rev. Sanid. milit. argent., 49: 327-336, 1950.

4. BEJARANO, J.F. - Complejo patógeno de la leishmaniasis en la República Argentina. In: JORNADAS DE ENTOMOEPIDEMIOLOGÍA ARGENTINAS, 1., Buenos Aires, 1959. Resúmenes. v. 2, p. 805-832.

5. BRAZIL, R.P.; DE ALMEIDA, D.C.; BRAZIL, B.G. \& MAMEDE, S.M.P.O. - Chicken house as a resting site of sandflies in Rio de Janeiro, Brazil. Parassitologia, 33 (suppl. 1): 113-117, 1991.
6. BROWN, A.D. - Las selvas de montaña del noroeste de Argentina: problemas ambientales e importancia de su conservación. In: BROWN, A.D. \& GRAU, H.R., ed. Investigación, conservación y desarrollo en selvas subtropicales de montaña. Tucumán, Laboratorio de Investigaciones Ecológicas de las Yungas; Universidad Nacional de Tucumán, 1995. p. 9-18.

7. CABRERA, A. \& WILLINK, A. - Biogeografía de América Latina. Washington, Secretaría General de la Organización de los Estados Americanos. 1980. (Monografia No. 13).

8. CAMPANINI, A.R.; SINAGRA, A.; SARAVIA, N. et. al. - Caracterización in vitro de aislados de Leishmania de pacientes de Salta. Medicina (B. Aires), 53 (supl. 1): 81, 1993.

9. CASTRO, M. - Diptera: Psychodidae - Phlebotominae. In: JORNADAS DE ENTOMOEPIDEMIOLOGíA ARGENTINAS, 1., Buenos Aires, 1959. Resúmenes. p. 545-546.

10. DEDET, J.P. - Épidémiologie des leishmanioses du nouveau monde. In: DEDET, J.P., ed. Les Leishmanioses. París, ELLIPSES AUPELF/UREF, 1999. p. 147-160.

11. DESJEUX, P. - Aspects de santé publique et lutte. In: DEDET, J.P., ed. Les Leishmanioses. París, ELLIPSES AUPELF/UREF, 1999. p. 227-236.

12. GRIMALDI Jr., G.; TESH, R.B. \& McMAHON-PRATT, D. - A review of the geographic distribution and epidemiology of leishmaniasis in the new world. Amer. J. trop. Med. Hyg., 41: 687-725, 1989.

13. GOMES, A. de C. \& GALATI, E.A.B. - Flebotomíneos de Londrina, Paraná (Brasil) e observações ecológicas sobre algumas espécies. Rev. Saúde públ. (S. Paulo), 11: 284-287, 1977.

14. GOMES, A. de C. \& GALATI, E.A.B. - Aspectos ecológicos da leishmaniose tegumentar americana. 5. Estratificação da atividade espacial e estacional de Phlebotominae (Diptera, Psychodidae) em áreas de cultura agrícola da região do Vale do Ribeira, Estado de São Paulo, Brasil. Mem. Inst. Oswaldo Cruz, 82: 467-473, 1987.

15. GOMES, A. de C.; BARATA, J.M.S.; ROCHA E SILVA, E.O. \& GALATI, E.A.B. Aspectos ecológicos da leishmaniose tegumentar americana. 6. Fauna flebotomínea antropófila de matas residuais situadas na região centro-nordeste do Estado de São Paulo, Brasil. Rev. Inst. Med. trop. S. Paulo, 31: 32-39, 1989.

16. MARCONDES, C.B. - A redescription of Lutzomyia (Nyssomyia) intermedia (Lutz \& Neiva, 1912), and resurrection of L. Neivai (Pinto, 1926) (Diptera, Psychodidae, Phlebotominae). Mem. Inst. Oswaldo Cruz, 91: 457-462, 1996.

17. MARCONDES, C.B.; LOZOVEI, A.L. \& VILELA, J.H. - Distribuição geográfica de flebotomíneos do complexo Lutzomyia intermedia (Lutz \& Neiva, 1912) (Diptera, Psychodidae). Rev. Soc. bras. Med. trop., 31: 51-58, 1998.

18. MARCONDES, C.B. \& BORGES, P.S.S. - Distinction of males of the Lutzomyia intermedia (Lutz \& Neiva, 1912) species complex by ratios between dimensions and by an artificial neural network (Diptera: Psychodidae, Phlebotominae). Mem. Inst. Oswaldo Cruz, 95: 685-688, 2000.

19. MINETTI, J.L. - Atlas climático del Noroeste Argentino. Tucumán, Laboratorio Climatológico Sudamericano; Fundación Carl C. Zon Caldenius; Facultad de Filosofía y Letras de la Universidad Nacional de Tucumán, 1999. p 70-94.

20. PATERSON, G.C. \& SHANNON, R.C. - Sobre una nueva especie del género Phlebotomus encontrada en las provincias del norte de la República. Bol. Inst. Clin. quir. (B. Aires) 2: 298-309, 1926.

21. PATERSON, G.S.; SHANNON, R.C. \& DEL PONTE, E. - Observaciones sobre la distribución de flebótomos en las provincias del noroeste de la República Argentina. Bol. Inst. Clín. quir. (B. Aires), 3: 751-756, 1927.

22. RANGEL, E.F.; SOUZA, N.A.; WERMELINGER, E.D. \& BARBOSA, A.F. - Infecção natural de Lutzomyia intermedia (Lutz \& Neiva, 1912), em área endêmica de leishmaniose tegumentar no estado do Rio de Janeiro. Mem. Inst. Oswaldo Cruz, 79: 395-396, 1984. 
23. FORATTINI, O.P.; PATTOLI, D.B.G.; RABELLO, E.X. \& FERREIRA, A.O. - Infecção natural de flebotomíneos em foco enzoótico de leishmaniose tegumentar no Estado de São Paulo. Rev. Saúde públ. (S. Paulo), 6: 431-433, 1972.

24. SALOMÓN, O.D. - Control vectorial de leishmaniosis en la región neotropical. Rev. Soc. Ent. argent., 58: 269-275, 1999.

25. SALOMÓN, O.D.; TRAVI, B.L. \& SEGURA, E.L. - Note on sandflies associated with a tegumentar leishmaniasis focus in Salta, Argentina, 1988. Rev. Inst. Med. trop. S. Paulo, 37: 91-92, 1995.

26. SALOMÓN, O.D. - Leishmaniasis: estrategias de control de bajo impacto ambiental. Rev. argent. Med., 1: 346-354, 1999.

27. SALOMÓN, O.D. - Vectores de leishmaniosis. In: SEIJO, A.C. et al., ed. Temas de zoonosis y enfermedades emergentes. Buenos Aires, Asociación Argentina de Zoonosis, 1998. p. 264-267.

28. SALOMÓN, O.D. - Phlebotominae sandflies at a leishmaniosis focus in Argentina. New Heaven, 1997. (MsPH Thesis - Dept. Epidemiology and Public Health/School of Medicine/Yale University).

29. SALOMÓN, O.D.; ZAIDENBERG, M.; BURGOS, R.; HEREDIA, V.I. \& CAROPRESI, S.L. - American cutaneous leishmaniasis outbreak, Tartagal city, province of Salta, Argentina, 1993. Rev. Inst. Med. trop. S. Paulo, 43: 105-108, 2001.

30. SALOMÓN, O.D.; BOGADO DE PASCUAL, M.; MOLINARI, M.L. \& VERRI, V. Study of a cutaneous leishmaniasis outbreak in General Vedia, province of Chaco, 1996. Rev. Inst. Med. trop. S. Paulo, 43: 99-104, 2001

31. SALOMÓN, O.D.; SOSA ESTANI, S.; CANINI, L. \& CÓRDOBA LANÚS, E. Leishmaniosis tegumentaria en un área con niveles epidémicos de transmisión, Salta, Argentina, 1998. Medicina (B. Aires), 61: 284-290, 2001.
32. SALOMÓN, O.D.; SOSA ESTANI, S.; MONZANI, S. \& STUDER, C. - Brote epidémico de leishmaniosis tegumentaria en Puerto Esperanza, provincia de Misiones, 1998. Medicina (B. Aires), 61: 385-390, 2001.

33. SALOMÓN, O.D.; ROSSI, G.C. \& SPINELLI, G.R. - Ecological aspects of Phlebotominae (Diptera, Psychodidae) in an endemic area of tegumentar leishmaniasis in the northeastern Argentina, 1993-1998. Mem. Inst. Oswaldo Cruz, (in press).

34. SEGURA, E.L.; JUAN, N.; PIQUIN, A.L. et. al. - Molecular and biologic characterization of Leishmania parasites implicated in an epidemic outbreak in northwestern Argentina. Parasit. Res., 86: 504-508, 2000

35. SOSA ESTANI, S.; CAMPANINI, A.; SINAGRA, A. et al. - Caracteristicas clínicas y diagnóstico de la leishmaniosis mucocutanea en pacientes de un área endémica de Salta. Medicina (B. Aires), 58: 685-691, 1998.

36. VILLALONGA, J.F. - Leishmaniosis tegumentaria americana: clínica y tratamiento. Rev. Fac. Med. (Tucumán), 6: 197-208, 1963

37. VILLALONGA, J.F. - Leishmaniosis. In: ANTONI, S. \& RAIMONDO, O., ed. Temas de enfermedades infecciosas. Tucumán, El Graduado, 1998. p. 177-190.

38. YOUNG D.G. \& DUNCAN, M.A. - Guide to the identification and geographic distribution of Lutzomyia sand flies in Mexico, the West Indies, Central and South America (Diptera: Psychodidae). Mem. Amer. Ent. Inst., 54: 1-881, 1994.

39. WHO - Control of the Leishmaniases. Wld. Hlth. Org. techn. Rep. Ser., (793), 1990

Received: 11 October 2001

Accepted: 9 November 2001. 